\title{
The Impact of Educational Technologies on University Teachers' Self-efficacy
}

\author{
Nataliia Saienko, Yuliana Lavrysh and Valentyna Lukianenko \\ National Technical University of Ukraine “Igor Sikorsky Kyiv Polytechnic \\ Institute", Kyiv, Ukraine \\ https://orcid.org/0000-0001-8898-5198 \\ https://orcid.org/0000-0001-7713-120X \\ https://orcid.org/0000-0003-3748-2616
}

\begin{abstract}
The teaching profession is always evolving. Teachers have to upgrade their knowledge and skills to be in line with students' and employers' needs. The challenges teachers are facing are the continuously changing conditions of the teaching process and technological innovations. Unsuccessful and numerous attempts to overcome these challenges negatively affect teachers' self-efficacy. The purpose of the study was to investigate the impact of educational technologies on university teachers' self-efficacy level changes using quantitative (pre and post-self-efficacy test) and qualitative (peerobservation, interviews) research methods. The study involved 60 inservice ESP teachers with different length of teaching experience. Teachers were exposed to a short practical course on technologies integration into the teaching process, and after that, they had to demonstrate the practical application of the knowledge obtained. The findings showed that educational technologies integration had positive influence on four components of teachers' self-efficacy: classroom management, instruction strategies design, students' engagement and technologies integration. During the course delivery, we dealt with two problems: computer anxiety (senior teachers), as well as technology and pedagogical content knowledge framework (novice teachers).
\end{abstract}

Keywords: educational technologies; self-efficacy; classroom management; engagement

\section{Introduction}

The process of digitalization in education refers to the areas of socialization and human development. It is indisputable that the use of information technologies in education opens up new opportunities for both teachers and students to upgrade their creativity, acquisition and consolidation of professional competencies. Consequently, this process might increase the level of selfeducation and professional self-efficacy that will positively impact teacher's 
creativity, will create conditions to foster the professional development and selfrealization (Abbitt, 2011; Paraskeva et al., 2008).

Analysis of the world trends in the field of vocational education shows increasing requirements to pedagogical professionalism and personal qualities of a teacher. The main challenges teachers encounter with are a constant complication of the education content that enhances educational standards; the need for continuous professional development in terms of continually arising new educational technologies or innovations; adaptation of curricular to employers' and society changing requirements; performance in the information environment that implies a rational use of information technology in the educational process (Stavytskyi \& Urazgaliyeva, 2018; Istifci, 2019; Saienko \& Lavrysh, 2020; Stefancik \& Stradiotová, 2020; Saienko, Semyda \& Akhmad, 2020; Synekop, 2020).

To become a facilitator of educational technologies integration, educators should demonstrate their positive perception about technologies, high level of professional self-efficacy 'and self-confidence (Brinkerhoff, 2006; Kim et al., 2013; Ocak \& Baran, 2019). In Ukraine, teachers still demonstrate some technology anxiety, especially comparing with students who are "technology native". Teachers are afraid of making mistakes or admitting their lack of knowledge or skills. It prevents the integration of technologies and creation of facilitating an environment for studying that leads to students' loss of interest and, consequently, motivation to study. This gap between students' expectations and teachers' abilities leads to poor academic performance and teachers' disappointment in their profession and personal consistency. On the contrary, an adequate level of teachers' professional self-efficacy would lead to higher levels of job satisfaction and lower levels of job-related stress which will result in the enhancement of student learning achievement (Caprara et al., 2003; Fackler \& Malmberg, 2016).

Thus, the problem of studying the impact of educational technologies on university teachers' personal and professional characteristics is relevant, as a successful teacher should facilitative interaction with students by means of relevant and understandable for them tools. The specific objective of the study was to assess the impact of teachers' educational technologies integration skills on professional self-efficacy. The hypothesis of our research was to verify the assumption that if teachers employed educational technologies at their classes, it would increase the level of professional self-efficacy.

\section{Literature review}

Theory of self-efficacy was developed by Bandura (1999) in the seventies years of the last century. He believes that main factors of self-efficacy are the experience of previous success and failures, cognitive, emotional and physiological personal components, observation of others achievements and the ability to achieve one's personal goals (Bandura, 1999). He also states that the more pronounced sense of personal effectiveness and identity is in a person's perception, the more a person is internally motivated, because external 
motivation cannot compete with internal motivation in terms of personal influence. Bandura (1999) believes that the expectation of success is not sufficient to trigger the person's motivation. The key idea of the concept of self-efficacy is the assessment of personal ability to cope with a particular activity that previously seemed impossible. It may enhance the motivation level because selfefficacy is a crucial determinant of motivation.

While studying the literature sources, we singled out the most common for many researchers definition of self-efficacy. Some of the experts (Banoglu, Vanderlinde \& Yildiz, 2015) understand it as a judgment about people's ability to organize and perform some action required to achieve predefined output. The concept of "self-efficacy" is regarded as a combination of competences, necessary to achieve success, and confidence in his or her abilities to organize and perform specific actions to achieve the goal (Bandura, 1999). Teacher's self-efficacy might be demonstrated via analytical, prognostic, projective and reflexive cognitive skills. According to Bandura (1999), judgments on self-efficacy are based on four sources of information:

- successful implementation of activities;

- observation for people who have successfully mastered the skill;

- social approval;

- low level of anxiety associated with the action.

With a view of the successful combination of self-efficacy and digital competence, the scholars Tschannen-Moran and Woolfolk Hoy (2001) state that methods of self-efficacy development and assessment should be included into the educational programs for pre-service teachers as well as into the programs for continuous in-service teacher professional development. Prior studies on teachers' self-efficacy (Zajacova, Lynch \& Espenshade, 2005; Skaalvik \& Skaalvik, 2007) reveal a strong correlation between knowledge, skills, attitude and beliefs towards professional activity. On the contrary, a low level of perceived teacher self-efficacy leads to job stress and burnout (Schwarzer \& Hallum, 2008). However, these factors should be regularly updated on the demands of society, students and employers. In case it does not happen, students do not achieve curricular outcomes and teachers' self-efficacy level decreases.

On the basis of the resources studied, we define pedagogical self-efficacy as a belief, which is reflected in the teachers' confidence in their own professional competence, the ability to carry out pedagogical activity by choosing relevant tools, which will result in the achievement of the educational process outcomes. From the other side, Bandura (1999) defines factors that lower personality's selfefficacy. One of them is the loss of control over the process due to poor awareness of its nature. Teachers' inability to use and implement educational technologies might lower their self-esteem. The complicated educational technologies that are not subjected to the complete control might be a trigger for the process of self-efficacy falling. The issue of teachers' self-efficacy connection with educational technologies integration is supported by researchers who study the problem of "computer anxiety". Behavior in this state is characterized by the 
excessive caution when using computer or technologies, negative comments about information technology, and attempts to avoid technologies penetration into the professional area. Various authors (Howland, Jonassen \& Marra, 2012) highlight several ways to overcome computer anxiety:

- the formation of relevant motivational structure;

- preliminary practical training;

- the use of accelerating methods for the formation of skills necessary for working with technologies;

- familiarity with the technology as a tool for successful professional activity;

- friendly and creative learning environment;

- correspondence of the nature of information technology tools of the assigned pedagogical task.

Ertmer and Ottenbreit-Leftwich (2010), in their study regarding the influence of self-efficacy beliefs on technology integration point out on the connection between knowledge and self-efficacy beliefs by stating that "although knowledge of technology is necessary, it is not enough if teachers do not also feel confident using that knowledge to facilitate student learning"(p.261). Measures of both knowledge and beliefs independently can lead to obtaining valuable results regarding the preparation of instructors to use technology to create attractive and efficient classroom environments.

Self-efficacy beliefs regarding computer use impact teacher's ability to create technology-friendly learning environment. In this context, it is important to mention the research by Sahin, Akturk and Schmidt (2009) who investigated the relationship between pre-service teachers' perceived knowledge in Technological Pedagogical Content Knowledge (TPACK) domains and their selfefficacy beliefs regarding classroom teaching. The results showed that the high level of knowledge in TPACK will increase the level of pre-service teachers' selfefficacy. These results are in line with other research (Abbitt, 2011). It was proved that knowledge of technology increases self-efficacy beliefs about technology integration. Among the factors that influence the use of technology in the classroom, are self-efficacy beliefs, pedagogical beliefs, and cultural contexts (p.140). These results are important for us and in this paper we will focus on the issues of technology integration into education process and its impact on teachers' professional self-efficacy beliefs.

To sum up, all mentioned above, we consider self-efficacy as the leading regulatory setting that influences the alteration of personal behavior and thinking. Furthermore, we support the idea that one of the possible and promising ways to stimulate and motivate teachers to carry out an efficient pedagogical activity independently and creatively is the development of professional self-efficacy. 


\section{Methods}

\section{Research Design}

In order to verify the hypothesis of our research, we chose a mixed research methodology framework (Creswell, 2014) for the research performance. As it was necessary to know the level of teachers' efficacy, we employed a test with close-ended statements that represented us quantitative statistical data. Thus, we could merge, compare and connect the data with participants' apprehension of the researched question. As a tool for qualitative method we applied interview with open-ended questions to understand participants' attitude and perception of the issue. The combination of these tools supported the holistic approach to the research data analysis and provided us with general statistical and more personalized data. In the follow-up phase of the study, we carried out the confirmation and analysis of qualitative data with quantitative results, providing an understanding of results by consolidating the perspectives of individuals. Therefore, our research was conducted according to the following scheme: quantitative data collection and analysis followed up with qualitative data collection and analysis producing meaningful interpretation.

\section{Sample}

The sample consisted of 60 in-service English teachers selected from the Department of English for. The duration of their teaching experience was different: 18 teachers with less than two years of experience, 20 teachers with more than five years of experience and 22 teachers with more than 15 years of experience. Among other variables were educational materials of field-related orientation (humanities or engineering), number of students in groups, students' language level that caused mixed ability instructions, different technologies for integration according to planned syllabus outcomes. Among common conditions were: all teachers had insufficient skill in technologies integration, studentcentered approach to teaching, ESP related syllabus, 1 class of ESP (90 min) per week. The study aim and outcomes were explained to the participants. The respondents were not obliged to participate in the study. Test results and interviews answers were kept strictly confidential and were not identified by name.

\section{Instruments}

The most well-known tools for assessing efficacy are Schmitz and Schwarzer (1999)'s test and Bandura (1999) Teacher Self-efficacy Scales. These instruments are extensive and aimed at assessing the efficacy for teachers considering teachers' attitude towards their decision-making skills, instructional and disciplinary self-efficacy, parental and community involvement. However, we wanted to focus on teachers' efficacy regarding the successful and meaningful combination of such pedagogical skills as interaction with students and technological pedagogical content knowledge provision during formal education for students of universities. We consider these two pedagogical skills are the background for teachers to become closer to students, to test their needs, to get more positive feedback because teaching is a two-sided process and teachers' self-confidence and self-efficacy depend on the skills of smart communication with students. Therefore, we adapted a short version of a test 
(12 questions) developed by Tschannen-Moran and Woolfolk Hoy (2001) and added four items regarding education technologies implementation (Appendix 1). The original version of the test includes the assessment of three factors (four questions each): efficacy in student engagement, efficacy in instructional practices and efficacy in classroom management. Respondents assess their selfefficacy level using a 5-point scale answering the same question "How much can you do....?" ( 1 = nothing; 5 = a great deal of $)$. We carried out the test twice before and after the experiment to note the changes. To see qualitative changes, we used one performance-based peer-observation of a technology-enhanced class and an open-ended interview with teachers at the end of the experiment discussing reasons for changes, teachers' opinion about the experiment. The class peer observation instrument was a rubric that measured if the content, the proposed educational instructional strategies, and selected technology fitted together within the overall instructional plan and learning outcome. The rubric was an adaptation of a Technology Integration Assessment Rubric developed by Harris, Grandgenett and Hofer (2010) and involved the following factors for assessment: correspondence to curricular outcomes, matching the technology and instructional strategy, correlation of pedagogy and technology, students' engagement, effective technology operation. We chose this rubric as its assessment factors correlated with those ones that are assessed by self-efficacy test, namely: engagement, instructions, management and technology operation and correspondence to content and pedagogy. The interview addressed issues that emerged from the observations and allowed teachers to reflect on their actions and thoughts.

\section{Research Procedure and data analysis}

Before entering the experiment, teachers assessed their self-efficacy level employing our test. The results have been processed using the Fisher criterion (Sidorenko, 2000, pp.158-163). The second step was participation in a short introductory course on Educational Technology integration in terms of TPACK framework that combines pedagogical content knowledge, technological content knowledge and technological pedagogical knowledge (Schmidt et al., 2009; Koh, 2013; Kiray, 2016). The course goals were to help teachers redefine and reshape their perspectives and opinion regarding the use of educational technologies and to increase the awareness of technologies concepts to facilitate language learning and professional self-efficacy. The course included four topics: classification of educational technologies according to necessary skills development, designing activities and assessment, collaborating and personalized educational technologies for mixed-ability classes, applying project-based learning through educational technologies. The course involved two lectures (1.5-hour duration) on general information about technologies and five practical classes ( 2 hours each) where teachers could train their skills with chosen technology. The next step teachers conducted 3 ESP technology-enhanced classes, and one class had to be peer-observed. The last step was retaking self-efficacy test followed up with open-ended individual interviews focusing on the changes and their causes. 


\section{Results}

The first set of analyses examining the initial and final levels of self-efficacy revealed significant differences in data. For example, analyzing the dynamics of self-efficacy in novice teachers after the experiment (Table 1), we observed a significant increase in all factors of teachers' self-efficacy: Engagement, by $38 \%$ $(\varphi=4,68, p \leq 0,01)$; Instructional strategies, by $44 \%(\varphi=6,14, p \leq 0,01)$; Classroom management, by $36 \%(\varphi=4,68, p \leq 0,01)$; Technologies integration, by $53 \%(\varphi=$ $6,27, \mathrm{p} \leq 0,01)$.

Table 1. Self-efficacy in teachers with less than five years' experience $(n=18)$ before and after taking the course

\begin{tabular}{|l|c|c|c|c|c|}
\hline $\begin{array}{l}\text { Factors of teachers' } \\
\text { self-efficacy }\end{array}$ & $\begin{array}{c}\text { Initial level } \\
\text { (max.5points) }\end{array}$ & $\%$ & $\begin{array}{c}\text { Final level } \\
\text { (max.5 points) }\end{array}$ & $\%$ & $\boldsymbol{\varphi}^{*}$ \\
\hline Student engagement & 2,4 & 48 & 4,3 & 86 & $4,68^{*}$ \\
\hline $\begin{array}{l}\text { Instructional } \\
\text { strategies }\end{array}$ & 2,5 & 50 & 4,7 & 94 & $6,14^{*}$ \\
\hline $\begin{array}{l}\text { Classroom } \\
\text { management }\end{array}$ & 2,2 & 44 & 4 & 80 & $4,1^{*}$ \\
\hline $\begin{array}{l}\text { Technologies } \\
\text { integration }\end{array}$ & 2 & 40 & 4.8 & 96 & $7,27^{*}$ \\
\hline
\end{tabular}

${ }^{*} \mathrm{p} \leq 0,01$

The analysis of the dynamics of self-efficacy in teachers with more than 5 years of teaching experience before and after the experiment has also revealed a considerable difference by all the factors (Table 2): Engagement, by $30 \%(\varphi=4,89$, $\mathrm{p} \leq 0,01)$; Instructional strategies, by $8 \%$; Classroom management, by $12 \%$; Technologies integration, by $56 \%(\varphi=5,72, p \leq 0,01)$.

Table 2. Self-efficacy in teachers with more than five years of experience $(n=42)$ before and after taking the course

\begin{tabular}{|l|c|c|c|c|c|}
\hline $\begin{array}{c}\text { Factors of teachers' } \\
\text { self-efficacy }\end{array}$ & $\begin{array}{c}\text { Initial level } \\
\text { (max.5points) }\end{array}$ & $\mathbf{\%}$ & $\begin{array}{c}\text { Final level } \\
\text { (max.5 points }\end{array}$ & $\mathbf{\%}$ & $\boldsymbol{\varphi}^{*}$ \\
\hline Student engagement & 3,2 & 64 & 4,7 & 94 & $4,89^{*}$ \\
\hline $\begin{array}{l}\text { Instructional } \\
\text { strategies }\end{array}$ & 4 & 80 & 4,4 & 88 & - \\
\hline $\begin{array}{l}\text { Classroom } \\
\text { management }\end{array}$ & 3,5 & 70 & 4,1 & 82 & - \\
\hline $\begin{array}{l}\text { Technologies } \\
\text { integration }\end{array}$ & 1,5 & 30 & 4,3 & 86 & $5,72^{*}$ \\
\hline
\end{tabular}

${ }^{*} \mathrm{p} \leq 0,01$

Regarding the peer observation of a technology-enhanced class, the results presented the following data: all teachers integrated technology at their classes; 20 participants $(33,3 \%)$ used technologies for developing of language competences; 10 participants $(16,7 \%)$ used technologies for classroom 
management, engagement and assessment; $12(20 \%)$ teachers used technologies for collaboration skills development; 18 teachers (30\%) applied technologies for project-based learning.

The overall results of the peer observation indicated the positive assessment of technology-enhanced classes: $90 \%$ of participants exhibited meaningful integration of technology, pedagogy and content knowledge; $94 \%$ of observed demonstrated strong correlation of the technology and curricular outcome; $85 \%$ teachers used technology that supported instructional strategies; $88 \%$ of teachers succeeded in combining content, pedagogy and technology; in 96\% of observed classes students were fully engaged into the class; $73 \%$ of teachers operated the technology without technical problems. Among the problematic issues, we noted technical problems (Internet access, platforms compatibility, not suitable device settings ) - 15\%; poor students' engagement due to low students' technical or language background - 7\%; weak correlation of pedagogy and technology $-8 \%$; over usage of technology that affected classroom management $-6 \%$.

Another research analysis tool was an interview with teachers followed immediately after the class peer observation. The questions were mainly the same: what do you consider as the most beneficial strategy of the lesson? What was wrong? What would you change next time? Was technology integration supported with pedagogical strategy? What curricular outcome was achieved by the technology application? Did you feel more confident while conducting a technology-enhanced lesson? Describe the challenges you encountered while preparing or conducting the class. The questions presupposed open answers, and we used content analysis to interpret the data.

All responders $(n=60)$ agreed that technology integration facilitates communication with students and engagement as well as their motivation to study. Novice teachers $(n=18)$ admitted that due to technologies, they felt more confident dealing with classroom management by personalizing tasks according to students needs or background. Another benefit they indicated was the possibility to keep activities running smoothly by providing clear and meaningful instruction. Among teacher with professional experience, 17 participants admitted that their skills of instruction performance did not change much with technology integration. Majority of responders $(n=41)$ confessed that the most challenging issue was to produce meaningful pedagogy and technology combination relevant to the field-related content and teacher would like to have more training on this issue. A significant number of teachers $(n=52)$ found technologies efficient for the assessment as it became more objective, clear for students and provided immediate feedback or grading that was very important for students. Taken together, these results suggest that there is an association between educational technologies integration and professional selfefficacy level rising. The next part of the paper, therefore, moves on to discuss the challenges and perspectives for teachers' self-efficacy development. 


\section{Discussion}

One of the skills that teachers must acquire is how to integrate modern technology into teaching and learning in their classrooms. According to the data collected with respect to the barriers to technology integration, there occur difficulties in finding pedagogically sound technology for specific content and specific skills due to lack of professional development and constant development of new technologies (Schmidt-Crawford, Tai, Wang \& Jin, 2016). Among other challenges mentioned by teachers are the same as were discussed in the study of Ertmer et al. (2012): Internet access problems, price for devices, Web facilities, technical problems, lack of training. However, our experiment proves that all these problems can be solved if teachers feel inner motivation and get stimuli for professional development. After attending the course, visiting the classes of colleagues with followed up discussions, teachers got some ideas on how to create technology-friendly environment in the classroom. And the perception of this knowledge and successful implementation of their insights contributed to the self-confidence and self- efficacy levels elevation.

As it was mentioned by Howland et al. (2012), five factors demonstrate meaningful pedagogy and technology integration: duration, knowledge expression and reflection by means of technologies, authenticity, learning autonomy and development of cooperative skills, which is in line with our results. During the interviews, the majority of teachers reported the enhancement of students' academic achievements. Thus, students used technologies to articulate their reflections on subject matter, simulated realworld problems solutions via technologies, employed skills of self-learning to enrich their knowledge, realized interdisciplinary collaborative projects. All these positive changes impacted the general academic students' achievements and, as a consequence, led to the raising of teachers' self-efficacy level.

Teacher self-efficacy is an umbrella term for variables that might comprise its meaning depending on the subjects of teaching, institution type, personal characteristics etc. Moreover, recent works (Depaepea \& König, 2018) have shown positive correlations between teachers' self-efficacy and a range of instructional outcomes. In a view of modern educational trends, we consider the technology self-efficacy as a constituent that empowers teachers with confidence and bridges the gap between teachers and digitally native young generations.

It is worth mentioning the difference in self-efficacy tests results between inexperienced teachers, and experienced ones. Initial levels were higher among experienced teachers and it is explained by their self-confidence, minor cases of students' academic failures and skills gained through years of practice. However, they demonstrated the high level of technology anxiety and some extend of resistance to implement technologies not to lose the self- confidence and control over the educational process, which is in line with other studies (Manoj, Sanjay \& Aakriti, 2019; Setyarini, 2018). Another identified problem was connected with the low level of students' engagement. In contrast, novice teachers demonstrated the low level of classroom management and instructional strategies development. Teachers with less than five years of experience applied 
different technological tools but without any pedagogical support, just for the sake of using some interesting and interactive methods. Frequently such application did not correspond to any curricular outcome but stimulated students' motivation and engagement. The key problem novice teachers indicated was complete misunderstanding why these technologies did not lead to any sound results. Consequently, both groups of teachers felt professional disappointment and poor self-efficacy. Therefore, the key objectives of the course suggested to teachers, were to demonstrate experienced teachers how to combine technologies with their extended pedagogical knowledge, and what pedagogical content should be supported by technologies for novice teachers.

As we see from the quantitative data obtained by the self-efficacy test, the introduction of educational technologies impacted all components of teachers' self-efficacy. Analyzing the results of experienced teachers, we can state that two components were significantly changed: students' engagement and more meaningful and interactive pedagogical strategies application enhanced by relevant technologies. These components are interrelated due to interactivity, personalizing and student-centered nature of technologies (Martin \& Bolliger, 2018; Sawang, O'Connor \& Ali, 2017). Students demonstrated a higher level of confidence when they successfully performed tasks according to their educational background, were not afraid of subjective assessment and participated more actively in activities. A significant amount of authentic information suggested by the Internet stimulated ideas for projects and enabled students to feel like partners with teachers because both participants of the learning process had the knowledge to share. During the interviews, teachers told that when they observed these changes, they felt empowered by the increased personal value and self-efficacy that appeared due to the experience of having a real influence on students' motivation and behavior. The classroom management and instructions development did not change much significantly; however, on the interviews teachers noted that the meaning of these components changed. By using technologies experienced teachers accepted the idea that they were not a unique source of information anymore, and students were more knowledgeable in some professional areas. So, the key transformation of classroom management was the idea to use students as a source of information about technologies and turn students to partners aimed at achieving a common outcome. Therefore, we evidenced positive changes in all components and, as a result, total positive change in assessing self-efficacy.

The key transformation novice teachers admitted during the interviews was the evidenced results of technologies and pedagogy content combination stimulating methodological changes in the use of technologies. The priority was to determine the outcome and pedagogical strategy to achieve it, and only then to find technology relevant to the chosen pedagogical strategy. This transformation led to changes in instructions design and classroom management. New instructions implied using critical and creative thinking as well as the teamwork. It also made easier to manage the mix-ability groups as all students participated in activities according to their educational background and personal needs. All students got immediate feedback on their performance, so, 
the assessment did not take much time and even stimulated self-corrective work. All mentioned above facts allow us to claim that novice teachers' self-efficacy level increasing was proved by quantitative and qualitative results.

\section{Conclusions}

An initial objective of the research was to assess the impact of teachers' educational technologies integration skills on professional self-efficacy level. The research findings confirmed the hypothesis of the research, and we can state that technologies integration increased teachers' professional self-efficacy level. This correlation might be explained by the holistic nature and extended influence of technologies on crucial components of a teaching process: interaction with students, instructions design, assessment, students' engagement, classroom management, application of a wide range of educational strategies for the development of linguistic, field-related and twenty-first-century skills. Overall, the successful and meaningful employment of these tasks determines the level of teachers' self-efficacy. This study is limited by the number of respondents and geographical region, but in any way, this research showed the positive tendencies and might attract more interest to further study of this issue. In our future research, we intend to concentrate on broader spectrum of teacher beliefs regarding the use of education technologies in teaching foreign languages.

\section{References}

Abbitt, J. T. (2011) An Investigation of the Relationship between Self-Efficacy Beliefs about Technology Integration and Technological Pedagogical Content Knowledge (TPACK) among Preservice Teachers. Journal of Digital Learning in Teacher Education, 27(4), 134-143. https://doi.org/10.1080/21532974.2011.10784670

Bandura, A. (1999). Self-efficacy: Toward a unifying theory of behavioral change. In Roy F. Baumeister's (Ed.), The Self in Social Psychology (pp. 285-298). New York, NY, US: Psychology Press

Banoglu, K., Vanderlinde, R., \& Yildiz, R. (2015). Professional Self-Efficacy Scale for Information and Computer Technology Teachers: Validity and Reliability Study. Anthropologist, 20(1,2), 22-32. https://doi.org/0.1080/09720073.2015.11891720

Brinkerhoff, J. (2006). Effects of a Long-Duration, Professional Development Academy on Technology Skills, Computer Self-Efficacy, and Technology Integration Beliefs and Practices. Journal of Research on Technology in Education, 39(1), 22-43. https://doi.org/10.1080/15391523.2006.10782471

Caprara, G. V., Barbaranelli, C., Borgogni, L., \& Steca, P. (2003). Efficacy beliefs as determinants of teachers' job satisfaction. Journal of Educational Psychology, 95, 821-832. https://doi.org/10.1037/0022-0663.95.4.821

Creswell, J. W. (2014). Research design: Qualitative, quantitative and mixed methods approaches. SAGE.

Depaepea, F., \& König, J. (2018). General pedagogical knowledge, self-efficacy and instructional practice: Disentangling their relationship in pre-service teacher education. Teaching and Teacher Education, 69, 177-190. https://doi.org/10.1016/j.tate.2017.10.003

Ertmer, P. A., \& Ottenbreit-Leftwich, A. (2010). Teacher technology change: How knowledge, confidence, beliefs, and culture intersect. Journal of Research on Technology in Education, 255-284. https://doi.org/10.1080/15391523.2010.10782551 
Ertmer, P., Ottenbreit-Leftwich, A., Sadik, O., Sendurur, E., \& Sendurur, P. (2012). Teacher beliefs and technology integration practices: A critical relationship.

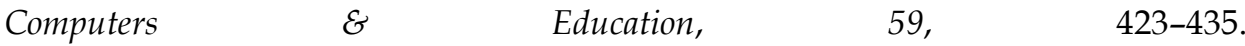
https://doi.org/10.1016/j.compedu.2012.02.001

Harris, J., Grandgenett, N., \& Hofer, M. (2010). Testing a TPACK-based technology integration assessment instrument. In C. D. Maddux, D. Gibson, \& B. Dodge (Eds.), Research highlights in technology and teacher education (pp. 323-331). Chesapeake, VA: Society for Information Technology and Teacher Education.

Howland, J., Jonassen, D., \& Marra, R. (2012). Meaningful learning with technology (4th ed.). Boston, MA: Allyn \& Bacon.

Istifci, I. (2019). A Case Study on Pre-Service English Teachers' Perceptions of SelfEfficacy and Integration of Information-Communication Technologies. In S. Sisman-Ugur \& G. Kurubacak (Eds.), Handbook of Research on Learning in the Age of Transhumanism (Advances in Educational Technologies and Instructional Design) (pp. 306-322). https://doi.org/10.4018/978-1-5225-8431-5.ch017

Fackler, S., \& Malmberg, L.-E. (2016). Teachers' self-efficacy in 14 OECD countries: Teacher, student group, school and leadership effect. Teaching and Teacher Education, 56, 185-195. https://doi.org/0.1016/j.tate.2016.03.002

Kim, C., Kim, M. K., Lee, C., Spector, J. M., \& DeMeester, K. (2013). Teacher beliefs and technology integration. Teaching and Teacher Education, 29, 76-85. https://doi.org/10.1016/j.tate.2012.08.005

Kiray, S., (2016). Development of a TPACK self-efficacy scale for pre-service science teachers. International Journal of Research in Education and Science, 2(2), 527-541. https:// doi.org/10.21890/ijres.64750

Koh, J. (2013). A rubric for assessing teachers' lesson activities with respect to TPACK for meaningful learning with ICT. Australasian Journal of Educational Technology, 29(6), 887-900. https://doi.org/10.14742/ajet.228

Martin, F., \& Bolliger, D. U. (2018). Engagement Matters: Student Perceptions on the Importance of Engagement Strategies in the Online Learning Environment. Online Learning, 22(1), 205-222. https:// doi.org/10.24059/olj.v22i1.1092

Manoj, K. S, Sanjay, K., \& Aakriti, S. (2019). Computer anxiety and individual failure in computer usage among teacher educators. International journal of information dissemination and technology, 9(4), 191-195. https://doi.org/10.5958/22495576.2019 .00037 .2

Ocak, C., \& Baran, E. (2019): Observing the Indicators of Technological Pedagogical Content Knowledge in Science Classrooms: Video-Based Research. Journal of Research on Technology in Education, 51(1), 43-62. https://doi.org/10.1080/15391523.2018.1550627

Paraskeva, F., Bouta, H., \& Papagianni, A. (2008). Individual characteristics and computer self-efficacy in secondary education teachers to integrate technology in educational practice. Computers $\mathcal{E}$ Education, 50(3), 1084-1091. https:// doi.org/10.1016/j.compedu.2006.10.006

Saienko, N., \& Lavrysh, Y. (2020). Mobile assisted learning for self-directed learning development at technical university: SWOT analysis. Universal Journal of Educational Research, 8(4), 1466-1474. https://doi.org/10.13189/ujer.2020.080440

Saienko, N., Semyda, O., \& Akhmad, I. (2020). Using social networks in teaching ESP to engineering students. Advanced Education, 7(14), 38-45. https://doi.org/10.20535/2410-8286.198083

Sahin, I., Akturk, A., \& Schmidt, D. (2009). Relationship of preservice teachers' technological pedagogical content knowledge with their vocational self-efficacy beliefs. In C. D. Maddux (Ed.), Research Highlights in Technology and Teacher Education (pp. 293-301). Chesapeake, VA: AACE. 
Sawang, S., O'Connor, P., \& Ali, M. (2017). IEngage: Using technology to enhance students' engagement in a large classroom. Journal of Learning Design, 10(1), 1119. https://doi.org/10.5204/jld.v9i3.292

Setyarini, M. C. E. (2018). Understanding Teachers' Computer Anxiety. ETERNAL (English Teaching Journal), 6(1), 74-87. https://doi.org/10.26877/eternal.v6i1.2297

Stavytskyi, O., \& Urazgaliyeva, M. (2018). Using Google classroom tools in teaching students of economic specialities. Advanced Education, 5(10), 76-81. https://doi.org/10.20535/2410-8286.149361

Stefancik, R., \& Stradiotová, E. (2020). Using Web 2.0 Tool podcast in teaching foreign languages. Advanced Education, 7(14), 46-55. https://doi.org/10.20535/24108286.198209

Schmidt-Crawford, D., Tai, S., Wang, W., \& Jin, Yi. (2016). Understanding Teachers' TPACK Through Observation. In M. C. Herring, M. J. Koehler \& P. Mishra (Eds.), Handbook of Technological Pedagogical Content Knowledge (TPACK) for Educators. Routledge. https://doi.org/10.4324/9781315771328

Schmidt, D., Baran, E., Thompson, A., Mishra, P., Koehler, M., \& Shin, T. (2009). Technological Pedagogical Content Knowledge (TPACK): The development and validation of an assessment instrument for preservice teachers. Journal of Research on Technology in Education, 42(2), 123-149. https:// doi.org/0.1080/15391523.2009.10782544

Schmitz, G. S., \& Schwarzer, R. (1999). Proaktive Einstellung von Lehrern: Konstrukt beschreibung und psychometrische Analysen [Proactive attitude of teachers: construct description and psychometric analyzes]. Empirische Pädagogik, 13(1), 327. Retrieved from https://www.fachportalpaedagogik.de/literatur/vollanzeige.html?FId=503968\#vollanzeige

Schwarzer, R., \& Hallum, S. (2008). Perceived teacher self-efficacy as a predictor of job stress and burnout: Mediation analyses. Applied psychology: an international review, 57, 152-171. https:// doi.org/10.1111/j.1464-0597.2008.00359.x

Sidorenko, E. (2000). Metody matematicheskoi obrabotki $v$ psikhologii [Methods of mathematical processing in Pychology]. St. Petersburg, Russia: Ltd Rech.

Skaalvik, E. M., \& Skaalvik, S. (2007). Dimensions of teacher self-efficacy and relations with strain factors, perceived collective teacher efficacy, and teacher burnout. Journal of Educational Psychology, 99, 611-625. https://doi.org/10.1037/00220663.99.3.611

Synekop, O. (2020). Webquest as technology of differentiated ESP instruction at university level. Journal of teaching English for specific and academic purposes, 8(1), 43-52. https:// doi.org/10.22190/jtesap2001043s

Tschannen-Moran, M., \& Woolfolk, H. A. (2001). Teacher efficacy: Capturing an elusive construct. Teaching and Teacher Education, 17, 783-805. https:// doi.org/10.1016/s0742-051x(01)00036-1

Zajacova, A., Lynch, S. M., \& Espenshade, T. J. (2005). Self-efficacy, stress, and academic success in college. Research in Higher Education, 46, 677-706. https://doi.org/10.1007/s11162-004-4139-z 


\section{Appendix 1}

Teachers' Self-efficacy test

1. How much can you do to control behavior in the classroom?

2. How much can you do to motivate students who show low interest?

3. How much can you do to get students to believe they can do well in studying?

4. How can you integrate the instructional strategies with technology?

5. How much can you do to help your students value learning?

6. To what extent can you craft good questions for your students?

7. How much can you do to improve your technology skills?

8. How much can you do to get students to follow classroom rules?

9. How much can you do to calm a student who is disruptive?

10. How well can you establish a classroom management system with each group of students?

11. How well do you select the technologies that you plan to use?

12. How much can you use a variety of assessment strategies?

13. To what extent can you provide an alternative explanation or example when students are confused?

14.To what extend does technology impact your classroom management?

15 . How much can you do to get students to work together?

16. How well can you implement alternative strategies in your classroom?

Efficacy in Student Engagement: 2, 3, 5, 15

Efficacy in Instructional Strategies: 6, 12, 13, 16

Efficacy in Classroom Management: 1, 8, 9, 10

Efficacy in Technologies Integration: 4, 7, 11, 14 